\title{
Pseudopodial silica absorption hypothesis (PSA hypothesis): a new function of pseudopodia in living radiolarian polycystine cells
}

\author{
KAORU OGANE ${ }^{*}$, NORITOSHI SUZUKI ${ }^{2}$, AKIHIRO TUJI $^{3} \&$ RIE S. HORI ${ }^{4}$ \\ ${ }^{1}$ Department of Geology, National Museum of Nature and Science, 4-1-1 Amakubo, Tsukuba, 305-0005, Japan \\ ${ }^{2}$ Institute of Geology and Paleontology, Graduate School of Science, Tohoku University, Sendai 980-8578, Japan \\ ${ }^{3}$ Department of Botany, National Museum of Nature and Science, 4-1-1 Amakubo, Tsukuba, 305-0005, Japan \\ ${ }^{4}$ Department of Earth Sciences, Graduate School of Science and Engineering, Ehime University, Matsuyama 790-8577, Japan \\ *Corresponding author (e-mail: ogane@mtc.biglobe.ne.jp)
}

\begin{abstract}
The secretion process of the siliceous skeleton in polycystine radiolarians has drawn a great deal of interest during the last century; however, little is known about the actual physiological process of silica deposition. Recently, the PDMPO (2-(4-pyridyl)-5-[(4-(2-dimethylaminoethylaminocarbamoyl) methoxy)-phenyl] oxazole) method for staining silica deposition sites in polycystines was developed. In the present study we examined over 30 polycystine cells with PDMPO and found that both the skeletons and pseudopodia of three species (Lithelius sp., Rhizosphaera trigonacantha and Arachnosphaera hexasphaera) were stained and emitted green fluorescent light. Staining of the skeleton was probably the result of skeletal thickening growth, whereas staining of the pseudopodia may indicate that siliceous matter is assimilated within pseudopodia. We refer to this hypothesis as the 'pseudopodial silica absorption hypothesis' (PSA hypothesis). If this hypothesis is correct, PSA is an intermittent process, and the absorbed silica within pseudopodia is quickly transferred to the cytokalymma where it is deposited on the skeleton. To date, the PSA process has been observed in only the three species cited above; therefore we are unable to evaluate whether the PSA process is unique to these species or a common process that occurs in all polycystines; further investigation is necessary.
\end{abstract}

KEYWORDS: Pseudopodial Silica Absorption hypothesis (PSA hypothesis), radiolaria, polycystine, silica assimilation process

\section{INTRODUCTION}

The process of silica secretion in polycystine radiolarians has long attracted interest among scientists (e.g. Thompson, 1942). The work of Hollande \& Enjumet (1960) made a significant contribution to understanding silicification within polycystines. Using thin sections, these authors observed a layer of cytoplasm on the siliceous skeleton of spheroidal polycystines. Anderson $(1976,1980,1981)$ confirmed the presence of a cytoplasmic sheath surrounding the skeleton by using light, transmitted electron and scanning electron microscopy. Anderson (1980, 1981) suggested that the silica skeleton is secreted in a sheath that he called the 'cytokalymma'. Anderson (1981) also found a granular matrix in the cytokalymma around the growing portion of the siliceous skeleton, and he believed that this granular matrix served as a nucleation site for silica deposition. Independent of these cytological examinations of silicification, great efforts have also been made to identify the signature of silicification and to reconstruct growth patterns in the siliceous skeleton of polycystines. Nishimura (1986, 1990) observed that, after etching with sodium hydrate, some broken Cenozoic fossils displayed concentric or overlapping siliceous lamellae on the corroded section of the skeleton. She considered these lamellar structures to be growth lines and suggested that the variable lamellae thicknesses accounted for variation in the thickness of the skeleton and the size of pore frames (Nishimura, 1986, 1990). Anderson \& Bennett (1985) and Matsuoka (1992) approximated the growth pattern of several flat-shaped polycystine species through comparisons of many individuals at various growth stages. According to these studies, flat polycystine species grow their skeleton by adding a new skeletal framework around their existing shells (Anderson \& Bennett, 1985; Matsuoka, 1992).

Despite these previous observations, little is known about the actual physiological process of silica deposition due to the very limited number of observations of this process in living polycystine cells. Although the growth process of siliceous skeletons has been confirmed in several flat-shaped polycystines (e.g. Dictyocoryne truncatum (Ehrenberg, 1861) and Spongaster tetras tetras Ehrenberg, 1861) through culturing experiments (e.g. Anderson et al. 1989; Matsuoka, 1992), direct observation and evidence of skeletal growth remain limited. In recent culture experiments, Ogane et al. (2009, 2010) directly examined silica deposition on the polycystine skeleton. These authors applied a fluorescent compound called PDMPO (2-(4-pyridyl)-5-[(4-(2-dimethylaminoethylaminocarbamoyl) methoxy) phenyl] oxazole) to stain living polycystine cells (Ogane et al., 2009). PDMPO stains the acidic portion of the cells, and Ogane et al. (2009) demonstrated that this compound is useful for detecting newly silicified skeletal parts in living polycystine specimens. Ogane et al. (2010) treated 22 living polycystines with PDMPO, ultimately revealing four different patterns of skeletal thickening growth (STG). PDMPO experiments have been shown to be highly effective for identifying the regions where silicification actually occurs in living polycystine cells.

Our team regularly examines many polycystine cells using PDMPO staining and we recently discovered that pseudopodia also emit the green fluorescent light of PDMPO, in addition to the skeleton. The phenomenon of fluorescing pseudopodia is considered to provide new evidence of the mechanisms of silicification in polycystine skeletons. Here, we will report the details of this phenomenon, and discuss the silicification process.

\section{MATERIALS AND METHODS}

The material was collected in waters SW of Sesoko Island, Okinawa Prefecture, Japan $\left(26^{\circ} 13^{\prime} 72^{\prime \prime} \mathrm{N}, 127^{\circ} 40^{\prime} 72^{\prime \prime} \mathrm{E}\right)$, on 25 

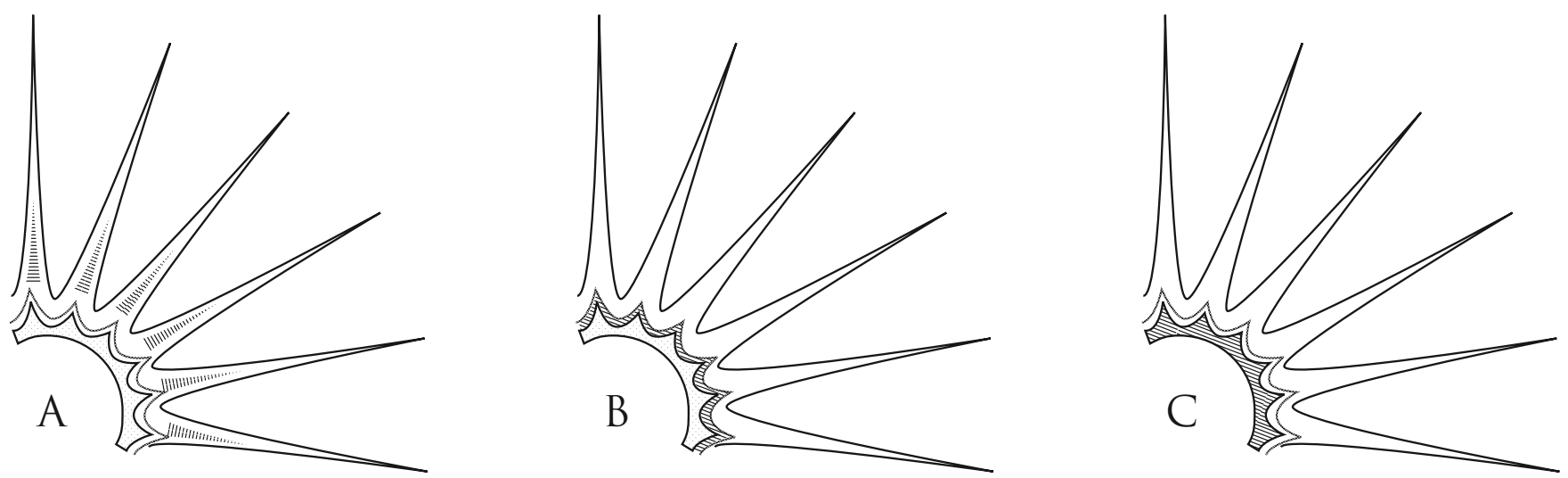

\section{Legend Accumulated silica in
acidic compartment Skeleton
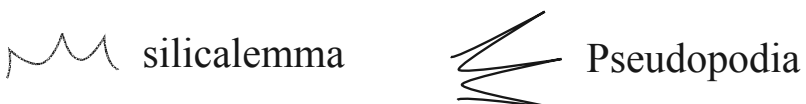

Cytoplasma

Fig. 1. Schematic illustration of the silica accumulation process of a polycystine cell: (a) polycystine cells accumulate silica in the pseudopodia; (b) accumulated silica is transferred to the silicalemma; (c) isolated silica deposited on the skeleton.

November 2008 during the 10th Radiolarian Observation Tour (hosted by Dr Atsushi Matsuoka, Niigata University). Samples were collected using a plankton net with $44 \mu \mathrm{m}$ mesh and a square frame whose side is $50 \mathrm{~cm}$ long. The water temperature was $24.6^{\circ} \mathrm{C}$, and salinity was 33 . The materials were immediately returned to the laboratory after sampling. Polycystine cells were extracted using Pustule pipettes under an inverted light microscope. The PDMPO experiment was performed as outlined in Ogane et al. (2010). The extracted cells were placed in a glass tube containing $16 \mathrm{ml}$ of seawater filtered through a $0.45 \mu \mathrm{m}$ membrane filter. The PDMPO (final concentration: $1.0 \mathrm{mM}$ ) was dissolved in $20 \mathrm{ml}$ seawater filtered in advance, and then added to the glass tube containing the polycystine cells. These tubes were incubated under red and blue LED lights for $12 \mathrm{~h}$ and in the dark for $12 \mathrm{~h}$ at $26^{\circ} \mathrm{C}$. After incubation, the samples were fixed with a $5 \%$ neutral formalin solution. The fixed materials were kept at $5^{\circ} \mathrm{C}$ prior to observation.

To observe the PDMPO staining, the material was placed on a glass slide and covered with a cover glass. Four lines of petroleum jelly were spread on to each side of the cover glass to prevent it from crushing the radiolarian specimen. All slides were observed under epifluorescence microscopy (AX-80, Olympus) with UV-excitation (WU: BP330-385, DM400, BA420), and images of selected cells were digitally captured using a CCD camera (DXM-1200, Nikon). After observation the specimens were washed from the slides, and other unstudied material discarded.

\section{RESULTS}

More than 30 cells of seven spumellarian and seven nassellarian species were stained with PDMPO. No collodarian species were found in the study material. Green fluorescence from pseudopodia was observed in three spherical spumellarian taxa: one Lithelius sp., two cells of Rhizosphaera trigonacantha Haeckel, 1860, and three cells of Arachnosphaera hexasphaera Popofsky, 1912, whereas we found no cells of nassellarian species with pseudopodia that emitted green fluorescent light.

\section{Lithelius sp.}

Two cells were identified as Lithelius sp., as we were unable to observe the key skeletal features for species identification. The genus Lithelius is the type taxon of the family Litheliidae Haeckel, 1862 and the superfamily Lithelioidea Haeckel, 1862. Cells of this morphotype are composed of deep brown intracapsulum and clear ectoplasm (P1. 1, figs 1a-b, 2a). Numerous pseudopodia are arranged radially around the cell (Pl. 1, figs 1a-b, 2a). Lithelius sp. has a subspherical skeleton with numerous radial spines. Two types of radial spines are identified, long and short. The long spines measure between 30 and $40 \mu \mathrm{m}$ and the short spines less than $10 \mu \mathrm{m}$.

Explanation of Plate 1. All the cells were collected SW of Sesoko Island, Okinawa Prefecture, SW Japan. figs 1-2. Lithelius sp.: 1a-b, transmitted light microphotographs of an entire fixed cell; 1c, fluorescent microphotograph of an entire fixed cell; 2a, enlarged transmitted light microphotograph of the periphery of the cell; $\mathbf{2} \mathbf{b}$, enlarged fluorescent microphotograph of the periphery of the cell. figs 3-4. Rhizosphaera trigonacantha Haeckel, 1860: 3a, enlarged transmitted light microphotograph of the periphery of the cell; $\mathbf{3} \mathbf{b}$, enlarged fluorescent microphotograph of the periphery of the cell; 4a-b, transmitted light microphotographs of an entire fixed cell; 4c, fluorescent microphotograph of an entire fixed cell. figs 5-6. Arachnosphaera hexasphaera Popofsky, 1912: 5a-b, transmitted light microphotographs of an entire fixed cell; 5c, fluorescent microphotograph of an entire fixed cell; 6a, enlarged transmitted light microphotograph of the periphery of the cell; $\mathbf{6} \mathbf{b}$, enlarged fluorescent microphotograph of the periphery of the cell. 
Silica absorption in living radiolarian polycystine cells
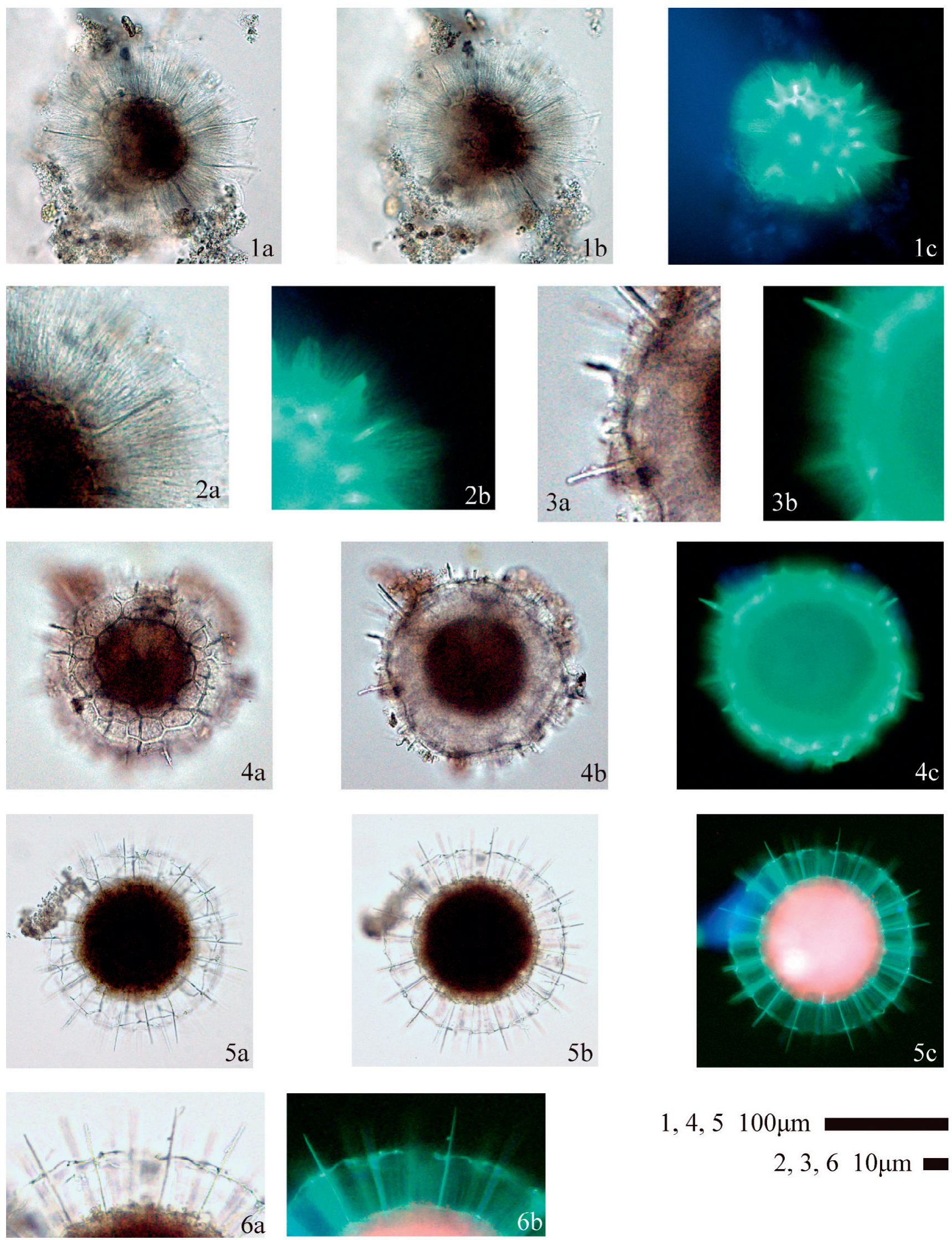
In the PDMPO experiments, both Lithelius cells emitted green fluorescent light from the observable cortical shells and spines (Pl. 1, fig. 1c). The cortical shell emitted dappled light. The long spines emitted green light from their bases, whereas the distal end of the spines did not emit fluorescent light. The short spines emitted green light from the base to the tip. Of these, only one cell showed green fluorescent light from its pseudopodia (Pl. 1, figs $1 \mathrm{c}, 2 \mathrm{~b})$. This light was fibrous, depending on the radial appearance of the pseudopodia around the extracapsulum.

\section{Rhizosphaera trigonacantha Haeckel, 1860}

Rhizosphaera trigonacantha is a spherical radiolarian polycystine that belongs to the family Rhizosphaeridae Haeckel, 1881 according to De Wever et al. (2001). The cells of this species are composed of deep brown intracapsulum and clear extracapsulum $(\mathrm{Pl}$. 1 , figs $3 a-b, 4 a-b)$. Its numerous pseudopodia are arranged radially around the intracapsulum (Pl. 1, figs $3 \mathrm{a}, 4 \mathrm{a}-\mathrm{b})$. Its skeleton is spherical with numerous radial beams and radial spines. The cytology, skeletal structure and pseudopodial activity of this species have been well documented by Suzuki (2005), and previous PDMPO experiments using this species were conducted by Ogane et al. (2010).

Five cells of $R$. trigonacantha were examined using PDMPO, and all cells emitted green fluorescent light from the entire observable framework of the spherical shell and radial spines (Pl. 1 , figs $3 b, 4 c)$. The bases of the radial spines gave especially bright light. Two of the cells emitted fluorescence from both their pseudopodia and skeleton. The green light emitted from the pseudopodia is fibrous, and arranged radially around the spherical shell. The light was stronger at the base of the pseudopodia.

\section{Arachnosphaera hexasphaera Popofsky, 1912}

Arachnosphaera hexasphaera is characterized by four or five concentric spherical shells with numerous radial spines originating from the innermost spherical shell ( $\mathrm{Pl}$. 1, figs 5a-b, 6a). This species is considered to belong to the family Astrosphaeridae Haeckel, 1887 by Mast (1910). Very fine pseudopodia radiate densely from the surface of the intracapsulum ( $\mathrm{Pl}$. 1, figs 5a-b, 6a). The intracapsulum is brown in nature, and encloses the inner three shells in young forms and the inner four shells in adult forms. Six to eight clusters of dark brown pigmented fine granules in the bundle of pseudopodia are the discriminating characters of the genus Arachnosphaera.

Six cells of this species were examined using PDMPO. All of these emitted bright green light from the observable skeletons outside of the intracapsulum. Three of these emitted bright green light from both the observable siliceous skeleton and pseudopodia (Pl. 1, figs 5c, 6b). Other pseudopodia with clusters of fine, dark brown granules tended to emit only weak light or none at all. Several bundles of pseudopodia that emitted green fluorescent light were also observed in one cell.

\section{DISCUSSION}

We examined two cells of Lithelius sp., five cells of $R$. trigonacantha and six cells of $A$. hexasphaera. All of these cells emitted the green fluorescent light following PDMPO-staining of their skeletons. One cell of Lithelius sp., two cells of $R$. trigonacantha and three cells of $A$. hexasphaera also fluoresced from their pseudopodia (Pl. 1, figs 1c, 2b, 3b, 4c, 5c, 6b). Our study is the first to confirm the emission of green fluorescent light from pseudopodia.

The green fluorescent light emitted from the skeleton was apparently caused by the effect of STG, a process of silica precipitation on polycystine skeletons (Ogane et al., 2010). Ogane et al. (2010) examined living cells of polycystines using PDMPO staining and documented that green fluorescent light was emitted from the entire outer shell. These authors concluded that the pattern of emitted green fluorescent light reflects the pattern of skeletal growth by polycystine cells (termed STG); the pattern is characterized by the addition of a thin layer of silica to the existing outer shells (Ogane et al., 2010). A similar pattern of green fluorescent light emission was observed in the present study and is therefore considered to result from the STG process.

A different interpretation, however, is required to explain the green fluorescent light emission from pseudopodia. The simplest interpretation is that the pseudopodia were strongly acidic. PDMPO is essentially used as a $\mathrm{pH}$ indicator, as the compound exhibits two distinct $\mathrm{pH}$-dependent peaks in both excitation and fluorescence spectra (Diwu et al., 1999). Although an accurate wavelength was not measured, the green fluorescent light emitted under the UV light of a mercury lamp observed in the present study generally indicates a $\mathrm{pH}$ of about 3 (Diwu et al., 1999). Therefore, it is possible that the green fluorescent light emitted from the pseudopodia was caused by strongly acidic low $\mathrm{pH}$ conditions in the pseudopodia. However, it is unlikely that green fluorescence is due solely to a low $\mathrm{pH}$ within the cytoplasm of the pseudopodia. After formalin (formaldehyde) fixation, the entire cell comes to equilibrium with the $\mathrm{pH}$ of the surrounding solution because formaldehyde destroys the selective semi-permeability of cytoplasmic membranes. The surrounding solution of the cells examined in this study was a mixture of $f / 2$ medium and neutral formaldehyde. Because both $\mathrm{f} / 2$ medium and neutral formalin are close to neutral, the solution surrounding the cells examined in this study would be close to neutral in $\mathrm{pH}$. In addition, if the $\mathrm{pH}$ of the formalin solution had caused a decrease in $\mathrm{pH}$ of the whole cytoplasm, all cells would have emitted green fluorescent light, which suggests that an acidic surrounding solution does not account for the fluorescing pseudopodia.

A more probable interpretation is that the green fluorescent light from the pseudopodia was caused by the accumulation of silica in the pseudopodia. In the presence of silicic acid, the fluorescent emission spectra of PDMPO are shifted to a single peak that occurs from 510 to $527 \mathrm{~nm}$ across a range of $\mathrm{pH} 3$ to 7 , and they then emit green fluorescent light under UV (Shimizu et al., 2001). Therefore, the green fluorescent light from pseudopodia may reflect the presence of silicic acid. Furthermore, the intensity of the fluorescent light emitted from the pseudopodia supports this interpretation. The fluorescent intensity of PDMPO increases with the concentration of silicic acid (Shimizu et al., 2001). The intensity of the green fluorescent light from the pseudopodia was comparable to that emitted from the skeletons, suggesting that the pseudopodia contained high levels of silica acid.

Although it is not clear why pseudopodia would contain high levels of silicic acid, one possible explanation may be that absorption and accumulation of silica occur within the pseudopodia (Fig. 1a), a process referred to here as the 'pseudopodial silica absorption' (PSA). The silica in pseudopodia is considered to be in unpolymerized or insufficiently polymerized form. If it were fully 
polymerized solid silica, quite fine fibrous skeletons would exist in the pseudopodia; however, such siliceous skeletons have never been observed in any pseudopodia. Furthermore, PSA is considered to be an intermittent process. All of the examined cells emitted green fluorescent light from their skeletons, whereas only about half of these cells showed green light from pseudopodia. The green fluorescent light from the skeleton suggests that all of these cells were alive because of their skeletal growth. On the other hand, the living cells without pseudopodia emitting green fluorescent light indicate that accumulated silica does not always occur in pseudopodia, which is consistent with PSA being an intermittent process in which the accumulated silica is rapidly transferred to the depositional site (Fig. 1b). According to Anderson (1980, 1981), the silica skeleton is deposited in a cytoplasmic sheath called a cytokalymma. Furthermore, Anderson (1994) suggested that the inner membrane of the cytokalymma acts as a silicalemma, i.e. the membrane of a silica deposition vacuole. However, it is not clear from these works whether or not the cytokalymma accumulates the silica. Under the PSA hypothesis, the cytokalymma would not be involved in silica accumulation, only in silica deposition (Fig. 1c).

Although PSA is a reasonable hypothesis, we cannot currently evaluate whether it is unique to the three species (i.e. Lithelius sp., $R$. trigonacantha and A. hexasphaera) examined here, or common to all polycystine radiolarian species. To verify the generality of the PSA hypothesis, further research is required; however, it is quite possible that the other species will exhibit PSA upon examination. Several species of flat Spumellaria (e.g. Dictyocoryne truncatum, Spongaster tetras tetras) show an intermittent growth process (Anderson et al., 1989; Matsuoka, 1992). Perhaps this intermittent growth process is caused by the intermittent nature of the PSA process.

Although questions remain, the PSA hypothesis offers an advance in understanding of silicification in polycystine radiolarians. The PSA hypothesis can be summarized in the following three steps (Fig. 1): (1) polycystine cells absorb dissolved silica through pseudopodia (Fig. 1a); (2) the accumulated silica is quickly transferred inside the silicalemma (Fig. 1b); and (3) the transferred silica is deposited on to the siliceous skeleton (Fig. 1c).

\section{CONCLUSION}

Here we present the first report of green fluorescent light emission from pseudopodia under PDMPO-staining, a phenomenon that can be explained by the assimilation process of silicic acid in the pseudopodia via the PSA hypothesis (pseudopodial silica absorption). If this hypothesis is correct, PSA is an intermittent process, and the accumulated silica in the pseudopodia is transferred to the silicalemma and deposited on to the growth site of the skeleton. However, it is not clear whether PSA occurs in all polycystine species, as the green light emitted from the pseudopodia has been observed in only three species to date, and further research is necessary to verify the PSA hypothesis.

\section{ACKNOWLEDGEMENTS}

We would like to thank Professor T. Danelian for giving us the opportunity to present our results during the Lille meeting and for his helpful advice on this manuscript. We also thank Drs O. R. Anderson and J. Dolven for their constructive reviews that improved the initial manuscript. This study is a result of the 10th Observation Tour of Living Radiolarians at the Sesoko Tropical Biosphere Research Center, University of the Ryukyus, hosted by $\operatorname{Dr}$ A. Matsuoka (Niigata University). We thank all the staff of the Sesoko Tropical Biosphere Research Center, University of the Ryukyus, and all participants of the tour for their kind help during field work. We also thank Mr S. Nakamura (University of the Ryukyus) for his kind assistance with sampling. Additional observational data were obtained with the financial support of the 'Integrated Research on Biodiversity of Interspecies Relationships' programme of the National Museum of Nature and Science (A. Tuji).

\section{Manuscript received 11 November 2013 \\ Manuscript accepted 11 November 2013 \\ Scientific Editing by Taniel Danelian}

\section{REFERENCES}

Anderson, O. R. 1976. A cytoplasmic fine-structure study of two spumellarian Radiolaria and their symbioses. Marine Micropaleontology, 1: $81-99$.

Anderson, O. R. 1980. Radiolaria. In Levandowsky, M. \& Hutner, S. (Eds), Biochemistry and Physiology of Protozoa, $2^{\text {nd }}$ edn. Academic Press, New York, 3: 1-40.

Anderson, O. R. 1981. Radiolarian fine structure and silica deposition. In Simpson, T. L. \& Volcani, B. E. (Eds), Silicon and Siliceous Structures in Biological Systems. Springer-Verlag, New York, 347-380.

Anderson, O. R. 1994. Cytoplasmic origin and surface deposition of siliceous structures in Sarcodina. Protoplasma, 181: 61-77.

Anderson, O. R. \& Bennett, P. 1985. A conceptual and quantitative analysis of skeletal morphogenesis in living species of solitary Radiolaria Euchitonia elegans and Spongaster tetras. Marine Micropaleontology, 9: 441-454.

Anderson, O. R., Bennett, P. \& Bryan, M. 1989. Experimental and observational studies of radiolarian physiological ecology: 1. Growth, abundance and opal productivity of the spongiose radiolarian Spongaster tetras tetras. Marine Micropaleontology, 14: 257-265.

De Wever, P., Dumitrica, P., Caulet, J. P., Nigrini, C. \& Caridroit, M. 2001. Radiolarians in the sedimentary record. Gordon and Breach, Amsterdam, $x x+533 p p$.

Diwu, Z., Chen, C., Zhang, C., Klaubert, D. H. \& Haugland, R. P. 1999. A novel aciclotropic $\mathrm{pH}$ indicator and its potential application in labeling acidic organelles of live cells. Chemistry and Biology, 6: 411-418.

Ehrenberg, C. G. 1861. Uber die Tiefgrund-Verhaltnisse des Oceans am Eingange der Davisstrasse und bei Island. Monatsberichte der Königlichen Preußischen. Akademie der Wissenschaften zu Berlin, 1861: 275-315.

Haeckel, E. 1860. Fernere Abbildungen und Diagnosen neuer Gattungen und Arten von lebenden Radiolarien des Mittelmeeres. Monatsberichte der Königlichen Preußischen Akademie der Wissenschaften zu Berlin, 1860: 835-845.

Haeckel, E. 1862. Die Radiolarien (Rhizopoda Radiolaria). Eine Monographie. Reimer, Berlin, 572pp.

Haeckel, E. 1881. Entwurf eines Radiolarien-Systems auf Grund von Studien der Challenger-Radiolarien. Jenaische Zeitschrift für Naturwissenschaft, 15: 418-472.

Haeckel, E. 1887. Report on the Radiolaria collected by H.M.S. Challenger during the years 1873-1876. In Thompson, C. W. \& Murray, J. (Eds), Report on the Scientific Results of the Voyage of H.M.S. Challenger During the Years 1873-1876, Zoology, 18: 1-1803.

Hollande, A. \& Enjumet, M. 1960. Cytologie, évolution et systématique des Sphaeroïdés (Radiolaires). Archives du Muséum National d'Histoire Naturelle, Série, 7: 1-134. 
Mast, H. 1910. Die Astrosphaeriden. Wissenschaftliche Ergebnisse der Deutschen Tiefsee-Expedition auf dem Dampfer "Valdivia" 1898-1899, 19: $123-190$.

Matsuoka, A. 1992. Skeletal growth of a spongiose radiolarian Dictyocoryne truncatum in laboratory culture. Marine Micropaleontology, 19: 287-297.

Nishimura, H. 1986. A preliminary report on growth of radiolarian shells. News of Osaka Micropaleontologists, Special Volume, 7: 157-165.

Nishimura, H. 1990. Taxonomic study on Cenozoic Nassellaria (Radiolaria). Science Reports of the Institute of Geoscience, University of Tsukuba, section B, Geological Sciences, 11: 69-172.

Ogane, K., Tuji, A., Suzuki, N., Kurihara, T. \& Matsuoka, A. 2009. First application of PDMPO to examine silicification in polycystine Radiolaria. Plankton and Benthos Research, 4: 89-94.
Ogane, K., Tuji, A., Suzuki, N., Matsuoka, A., Kurihara, T. \& Hori, R. S. 2010. Direct observation of the skeletal growth patterns of polycystine radiolarians using a fluorescent marker. Marine Micropaleontology, 77: 137-144.

Popofsky, A. 1912. Die Sphaerellarien des Warmwassergebietes. Deutsche Südpolar-Expedition 1901-1903, Zoologie, 13: 73-159.

Shimizu, K., Del Amo Y., Brzezinski, M. A., Stucky, G. D. \& Morse, D. E. 2001. A novel fluorescent silica tracer for biological silicification studies. Chemical Biology, 8: 1051-1060.

Suzuki, N. 2005. Physiological axopodial activity of Rhizosphaera trigonacantha Haeckel (a spheroidal radiolarian, Polycystina, Protista). Marine Micropaleontology, 54: 141- 153.

Thompson, D. W. 1942. On Growth and Form. Macmillan, New York, 1116pp. 